\title{
Obecność anioła w opowiadaniu o najeździe Sennacheryba na Jerozolimę w Syr 48,21
}

The Angel in the Narration on Sennacherib's Invasion of Jerusalem in Sir 48:21

\author{
JOLANTA JUDYTA PUDEŁKO \\ Papieski Wydział Teologiczny w Warszawie \\ e-mail: judyta.pd@gmail.com \\ ORCID: 0000-0001-5392-4109
}

\begin{abstract}
Aвstract: Biblical books, while presenting events from the history of biblical Israel, interpret them in a theological manner. This principle also applies to the description of Sennacherib's military campaign against Judah and Jerusalem in 701 BC. This campaign is even reported in the Assyrian sources, which underline Assyrian military power. The biblical narrative emphasizes an extraordinary intervention of God, who saves his people in a mysterious way. This divine intervention was so important that is was reported in the Old Testament writings four times (2 Kgs 19:35; 2 Chr 32:21; Is 37:21; Sirach 48:21). Biblical reports explains the rescue of Jerusalem by the intervention of God, who is acting by his "messenger" - an angel. In the latest description of this event, found in Ben Sira 47:21H, the sage from Jerusalem gives his own interpretation of the whole affair, which differs slightly from other reports. The angel, by whom God is acting, is identified with the prophet Isaiah, who announces the salvage of Jerusalem as an answer to people's prayers.
\end{abstract}

KeYwords: Old Testament, Book of Sirach, Praise of the Ancestors, Angel of the Lord, Sennacherib's invasion of Judah, Sir 48:18-21

SŁowa KLuczowe: Stary Testament, Księga Syracha, Pochwała ojców, Anioł Pana, najazd Sennacheryba na Judę, Syr 48,18-21

Kąa j sięgi biblijne przedstawiają wydarzenia $\mathrm{z}$ historii biblijnego Izraela, interpretuąc je w kluczu teologicznym. Dotyczy to również opisu najazdu króla Asyrii Sennacheryba na Judę i Jerozolimę w 701 r. przed Chr. Konfrontacja ta znalazła nawet odzwierciedlenie w źródłach asyryjskich, które podkreślają potęgę Asyrii. Jednak przekaz biblijny uwidacznia niezwykłą interwencję Boga, który w tajemniczy sposób ocalił swój lud. Był to przekaz tak istotny, iż został przedstawiony w Starym Testamencie aż cztery razy: 2 Krl 19,35; 2 Krn 32,21; Iz 37,21 oraz Syr 48,21. Przekazy biblijne thumaczą ocalenie Jerozolimy interwencją Boga, który działa poprzez swojego „posłańca” - anioła. Warto przyjrzeć się najpóźniejszemu opisowi tego wydarzenia w Syr 48,21 $1^{1}$ wraz z jego kontekstem, gdzie mędrzec z Jerozolimy daje własną, nieco odmienną od pozostałych, interpretację wydarzenia.

1 W związku z problematyką tekstualną Księgi Syracha, tekst Syr 48,21 będzie rozpatrywany w trzech wersjach: greckiej $(\mathrm{G})$, hebrajskiej $(\mathrm{H})$ i syryjskiej $(\mathrm{S})$. 


\section{Najazd Sennacheryba na Jerozolimę w Biblii i przekazach historycznych}

Najazd Sennacheryba na Judę i Jerozolimę miał miejsce podczas panowania króla Ezechiasza (727-697 przed Chr.), który podjął się dzieła religijnej reformy Królestwa Judy. Była to reakcja na działania, które prowadził podczas swego życia jego ojciec Achaz oraz wcześniejsi władcy. Reforma Ezechiasza (2 Krl 18,4-6) polegała między innymi na eliminacji obcych kultów: usunął wyżyny, zniszczył stele, wyciął aszery, rozbił węża miedzianego. Oczyścił więc kult jahwistyczny i religię z naleciałości pogańskich, które były tolerowane przez jego poprzedników, oraz wzmocnił centralną pozycję świątyni jerozolimskiej². Nie wydaje się jednak, iż reforma ta stała się bezpośrednim powodem konfliktu z Asyrią. Przez pierwsze lata swego panowania Ezechiasz płacił trybut Asyrii i był jej wasalem. Jednak być może, to właśnie upadek Samarii skłonił króla do podjęcia działań w celu uniknięcia losu oddanych kultom bałwochwalczym północnych sąsiadów³. Przez pierwsze lata rządów Ezechiasz kontynuował politykę zależności od Asyrii, prowadzoną przez swojego ojca Achaza. Źródła asyryjskie nie podają żadnych wzmianek o jakichkolwiek najazdach Asyrii na Judę. Pomimo że Sargon II przeprowadził trzy kampanie w celu zdławienia buntów w regionie Syrii-Palestyny (w latach 720-719; 716-715; 712-711), Juda nigdy nie była uczestnikiem tych buntów ${ }^{4}$. Dobre relacje pomiędzy Judą i Asyrią skończyły się wraz ze śmiercią Sargona II i wstąpieniem na tron jego syna Sennacheryba (705-681). Po śmierci Sargona bunty wybuchały w całym imperium asyryjskim, od Babilonii do Egiptu. Najprawdopodobniej Ezechiasz chciał wykorzystać zmianę władcy w Asyrii

2 J. Rosenbaum na temat reform Ezechiasza wypowiada się następująco: "The Chronicler's depiction of Hezekiah's reform (2 Chr 29:1-31:21) departs strikingly in length and detail from the Deuteronomistic History's brief version (2 Kgs 18:4, 16, 22). In both, Hezekiah is depicted as a king who «did right in the eyes of YHWH» and who inaugurated a religious reform which included the removal of the bāmôt («high places» of decentralized worship and sacrifice), the shattering of the sacred pillars (mașseebôt), the cutting down of the Asherah, and the refurbishing of the Jerusalem temple (to which $2 \mathrm{Kgs}$ 18:16 gives only passing, backhanded acknowledgement). Chronicles depicts other major details of the reform (Passover celebration and invitation to remnants in the North, establishment of covenant), which are omitted by 2 Kings. On the other hand, the Deuteronomistic History alone (2 Kgs 18:4) credits Hezekiah with destroying the Nehushtan associated with Moses". J. Rosenbaum, „Hezekiah, King of Judah”, The Anchor Yale Bible Dictionary (red. D.N. Freedman) (New York: Doubleday 1990) III, 190; por. A. Piwowar, Historia Izraela czasów Starego Testamentu. Od patriarchów do podboju przez Rzymian (Materiały Pomocnicze do Wykładów z Biblistyki 12; Lublin: Wydawnictwo KUL 2013) 155.

3 J. Bright (Historia Izraela [przeł. J. Radożycki] [Warszawa: PAX 1994] 285) uważa, iż reforma religijna Ezechiasza miała doprowadzić do zjednoczenia politycznego Izraela i Judy oraz do ich niepodległości.

4 Por. L. Stachowiak, „Imperium Neoasyryjskie a Juda w II. Połowie w. VIII”, RTK 29/1 (1982) 36. Ezechiasz został zaproszony do koalicji antyasyryjskiej (por. Iz 18), ale wyraźny sprzeciw proroka Izajasza powstrzymał króla od tego kroku (por. Iz 20). Por. Bright, Historia Izraela, 290. 
i formalnie odmówił płacenia daniny $(2 \mathrm{Krl} 18,7)^{5}$. Ponadto powziął pewne kroki zmierzające do osiągnięcia niepodległości, powiększył Jerozolimę i umocnił ją nowym murem, przygotował tunel Siloam oraz królewskie magazyny żywności ${ }^{6}$. Bunt Babilonii skierowany przeciwko Asyrii rozszerzył się na okolicznych asyryjskich wasali. Babilończycy pozyskali przychylność władców Sydonu, Aszkelonu, Ekronu i Judy, a Egipt popierał ten bunt, widząc w nim możliwość odzyskania pozycji lidera w kontrolowaniu szlaków handlowych Syrii i Palestyny? ${ }^{7}$ W $701 \mathrm{r}$. przed Chr., po uciszeniu buntów Babilończyków, Sennacheryb zwrócił się przeciwko buntownikom w Syrii i Palestynie. Zdławił opór w miastach filistyńskich, pomimo wsparcia ze strony Egiptu. Następnie wojska asyryjskie skierowały się w głąb Judy. Ponieważ Ezechiasz nie poddał się, król zburzył czterdzieści sześć jego warowni z niezliczonymi wioskami w regionie, między innymi ważną twierdzę Lakisz (2 Krl 18,13)9. Atak ten zmusił Ezechiasza do zapłacenia Asyrii wysokiego trybutu, o którym pisze również autor $2 \mathrm{Krl}$ : „Wtedy Ezechiasz, król judzki, wysłał poselstwo do króla asyryjskiego do Lakisz ze słowami: «Zbłądziłem. Odstąp ode mnie! Cokolwiek jako karę na mnie nałożysz, zniosę to». Król asyryjski zażądał od Ezechiasza, króla Judy, trzystu talentów srebra i trzydziestu talentów złota. I Ezechiasz oddał wszystkie pieniądze, jakie znajdowały się w świątyni Pańskiej i w skarbcach pałacu królewskiego. W tym samym czasie Ezechiasz kazał zerwać obicia drzwi i futryn świątyni Pańskiej, które król judzki Ozjasz kazał obić

5 Por. Bright, Historia Izraela, 293; M. Liverani, Nie tylko Biblia. Historia starożytnego Izraela (thum. J. Puchalski) (Biblioteka humanisty; Warszawa: Wydawnictwo Uniwersytetu Warszawskiego 2010) 163.

6 Por. Piwowar, Historia Izraela, 155.

7 Por. M. Grant, Dzieje dawnego Izraela (thum. J. Schwakopf) (Warszawa: Państwowy Instytut Wydawniczy 1991) 163-164; J. Warzecha, Historia dawnego Izraela (Warszawa: Wydawnictwo Uniwersytetu Kardynała Stefana Wyszyńskiego 2005) 313; Piwowar, Historia Izraela, 156. Liverani (Nie tylko Biblia, 163) jest zdania, iż Ezechiasz był przywódcą buntu przeciw Asyrii: „A jego sąsiedzi, czując się zagrożeni, zwrócili się oczywiście o pomoc do władcy asyryjskiego, co w $701 \mathrm{r}$. spowodowało wojskową interwencję Senacheryba".

8 Por. Stachowiak, „Imperium Neoasyryjskie”, 38. Liverani (Nie tylko Biblia, 163) stwierdza: “Wydaje się pewne, że Ezechiasz - wspierany przez wojsko egipskie - rozszerzył swe wpływy na Ekron i Aszkelon, podżegając tam do rewolty przeciw lokalnym królom wiernym Asyrii (zostali oni zastąpieni przez królów o nastawieniu antyasyryjskim). Interwencja Senacheryba zakończyła się dla niego korzystnie, nie przyniosła jednak ostatecznego rozstrzygnięcia: Egipcjanie zostali pobici w polu pod Elteqe (niedaleko Timny), miastom filistyńskim przywrócono królów proasyryjskich, judzka równina Szefela została zniszczona, a następnie przekazana proasyryjskim miastom filistyńskim".

9 Wśród zniszczonych 46 miast znajdowało się Lakisz, które osłaniało dostęp do Jerozolimy od południa i strzegło szlaku handlowego. Była to ważna twierdza królów Judy, położona między Jerozolimą i Gazą, drugie co do wielkości miasto w królestwie. Miasto to zostało przyłączone do terytorium asyryjskiego, stając się częścią terenu zarządzanego przez wasalnych władców filistyńskich. Por. Piwowar, Historia Izraela, 155. Bright (Historia Izraela, 295) stwierdza: „Wykopaliska w Lakisz, mieście, które Sennacheryb wziął szturmem, odsłaniają, oprócz śladów zniszczeń, ogromny dół, do którego wrzucono około 1500 ciał i przykryto świńskimi kośćmi i innymi śmieciami, przypuszczalnie pozostałościami po armii asyryjskiej”. 
metalem, i dał je królowi asyryjskiemu" ( $2 \mathrm{Krl} 18,14-16)$. W przekazie asyryjskiego króla Ezechiasz został dosadnie poniżony, a trybut okazał się być o wiele większy: „Judejczyk Ezechiasz, który nie poddawał się mojemu jarzmu (...) zamknąłem go w Jerozolimie jak ptaka w klatce. Usypałem przeciw niemu szańce ziemne i kto chciał wyjść z bram miasta był z powrotem zepchnięty w swą nędzę (...) Ezechiasz był przerażony blaskiem mojego dworu, a najemnicy, których sprowadził by wzmocnić Jerozolimę, opuścili go. Poza 30 talentami złota i 800 talentami srebra, musiał wysłać mi do Niniwy, mego królewskiego miasta, cenne kamienie i klejnoty, łoża i trony z kości słoniowej, skóry i kły słoniowe, drogocenne drewno, skarby każdego rodzaju, nawet swe córki, kobiety z pałacu, muzyków mężczyzn i kobiety"10. Jednak Jerozolima, pomimo długiego oblężenia, asyryjskich nasypów, nie została zdobyta ani poddana. Wydaje się, iż Asyria odniosła zwycięstwo. Czy wtedy ostatecznie armia asyryjska wycofała się z obleganej Jerozolimy? Czy była to strategiczna decyzja Sennacheryba, który uznał, iż zwycięstwo nad Judą dokonało się, a Ezechiasz znów stał się jego wasalem? A może wolał skoncentrować się na innej, bardziej newralgicznej części imperium? Skomplikowana relacja $2 \mathrm{Krl}$ o wyprawach Sennacheryba do Judei spowodowała, że niektórzy uczeni zasugerowali, że w rzeczywistości były dwie kampanie asyryjskie przeciwko Judzie ${ }^{11}$. Pierwsza zakończona zapłaceniem daniny miałaby miejsce w $701 \mathrm{r}$. przed Chr. (2 Krl 18,13-16), druga zaś zakończona niespodziewanym i tajemniczym ocaleniem Jerozolimy miałaby miejsce w $689 / 688$ r. przed Chr. (2 Krl 19,9-37) ${ }^{12}$. Czy więc mamy do czynienia z jedną dwufazową kampanią, czy też wojska asyryjskie faktycznie wycofały się i wróciły do Judei? Przyczyną wycofania mógł być ponowny bunt Babilończyków lub inna interwencja militarna. 2 Krl 19,9 sugeruje taką przyczynę pisząc o królu Kusz, imieniem Tirhaka, który wyruszył przeciwko Sennacherybowi. Wyprawa ta, podobnie jak oblężenie Jerozolimy, zakończyła się odwrotem wojsk asyryjskich ${ }^{13}$. Jednak według Józefa Flawiusza Sennacheryb po uzyskaniu trybutu od Ezechiasza udał się walczyć do Egiptu, pozostawiając swych dowódców, aby dalej oblegali Jerozolimę: „Asyryj-

10 D.D. Luckenbill, The Annals of Sennacherib (Chicago: University Press 1924) 33-34, cytuję za: Liverani, Nie tylko Biblia, 164.

11 Por. J.B. Geyer, „2 Kings XVIII 14-16 and the Annals of Sennacherib”, Vetus Testamentum 21 (1971) 604-606. Na temat kompozycji opowiadania o najeździe asyryjskim na Judę zob. N. Nadav, „Updating the Messages: Hezekiah's Second Prophetic Story (2 Kings 19,9b-35) and the Community of Babylonian Deportees", Like a Bird in a Cage (red. L.L. Grabbe) (Sheffield: Sheffield Academic Press 2003) 201-220.

12 Por. Bright, Historia Izraela, 295-296; Piwowar, Historia Izraela, 158.

13 W wyniku kolejnych buntów Sennacheryb ponownie najechał Judę i nizinę nadmorską. Znów zażądał od Ezechiasza poddania się. Jednak pomimo zwycięstwa króla Asyrii nad Tirhaką, Jerozolima nie została zdobyta. Por. Bright, Historia Izraela, 295-296. Do konfrontacji między Sennacherybem a Tirhaką odnosi się Herodot (Dzieje [tłum. S. Hammer] [Warszawa: Czytelnik 2015] II, 141.), dając przykład niezwykłego pojawienia się myszy polnych, które niszcząc kołczany i łuki Asyryjczyków, zmusily ich do odwrotu. 
czyk jednak, skoro otrzymał [pieniądze], nie zwracał uwagi na zawartą umowę, lecz sam wyruszył przeciwko Egipcjanom i Etiopom, a swego wodza Rapsakesa [Rabsaka] zostawił na czele mnogich zastępów i jeszcze dwóch innych dowódców zostawił z rozkazem złupienia Jerozolimy; tych zaś dwóch imiona były Tarata i Aracharis" (Ant 10.1.4). Co spowodowało niepowodzenie oblężenia? Być może wojska asyryjskie zniechęciły się dobrze przygotowaną obroną Jerozolimy, a może w obozie asyryjskim wybuchła epidemia? ${ }^{14}$ A może stało się jeszcze coś innego, co trudno jest wyjaśnić z historycznego punktu widzenia. Józef Flawiusz na podstawie przekazu biblijnego wyjaśnia cudowną interwencją Boga w następujący sposób: „Kiedy zaś Senacheirimos [Sennacheryb] wracając z wojny egipskiej, podążył ku Jerozolimie zastał tam wojsko pod wodzą Rapsakesa [Rabsaka]. Bóg rzucił na jego armię złośliwą zarazę, że podczas pierwszej nocy oblężenia wyginęło sto osiemdziesiąt pięć tysięcy wojowników wraz z dowódcami i oficerami" (Ant 10.5.21). Flawiusz poddaje zatem cudowne wydarzenie biblijne racjonalnej ocenie ${ }^{15}$. Jak zatem rozumieć biblijny przekaz o ocaleniu Jerozolimy z oblężenia wojsk asyryjskich?

\section{Cudowne wyzwolenie Jerozolimy z oblężenia asyryjskiego według przekazów biblijnych}

Stary Testament przedstawia aż cztery przekazy o cudownym wyzwoleniu Jerozolimy z oblężenia asyryjskiego: $2 \mathrm{Krl}$ 19,35; $2 \mathrm{Krn}$ 32,21; Iz 37,36 oraz Syr 48,21.

\begin{tabular}{|c|c|c|}
\hline $2 \mathrm{Krl} 19,35$ & $\mathrm{BH}$ & 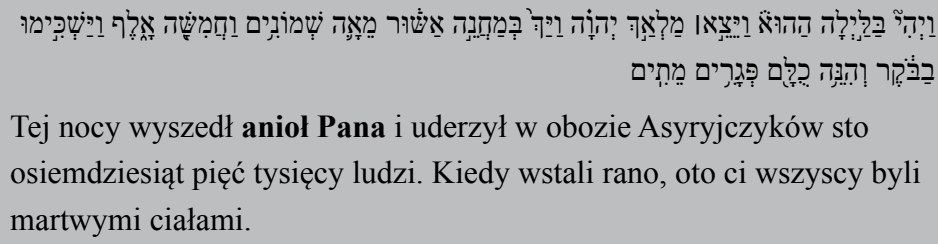 \\
\hline $2 \mathrm{Krl} 19,35$ & LXX & 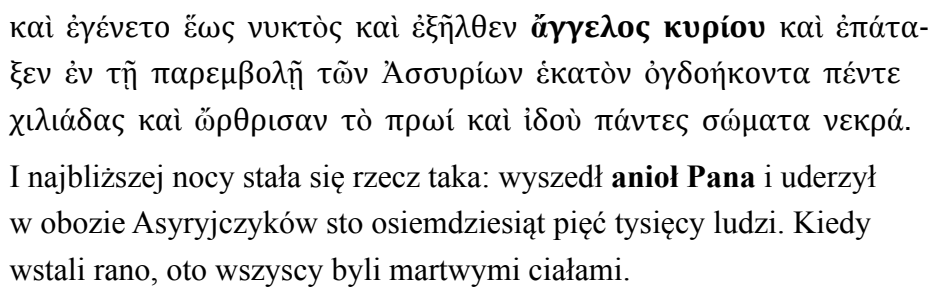 \\
\hline
\end{tabular}

14 Tak sugerują: Bright, Historia Izraela, 296; Grant, Dzieje dawnego Izraela, 164; Liverani, Nie tylko Biblia, 164.

15 Por. S. Bar, „The Destroying Angel”, Jewish Bible Quarterly 42/4 (2014) 258. 


\begin{tabular}{|c|c|c|}
\hline $2 \mathrm{Krn} 32,21$ & $\mathrm{BH}$ & 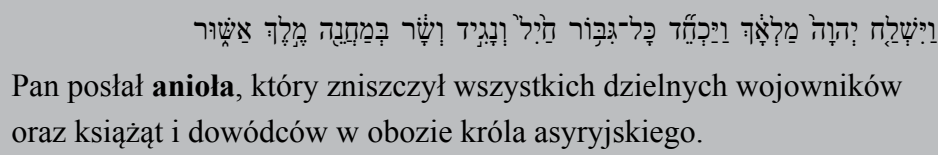 \\
\hline $2 \mathrm{Krn} 32,21$ & LXX & 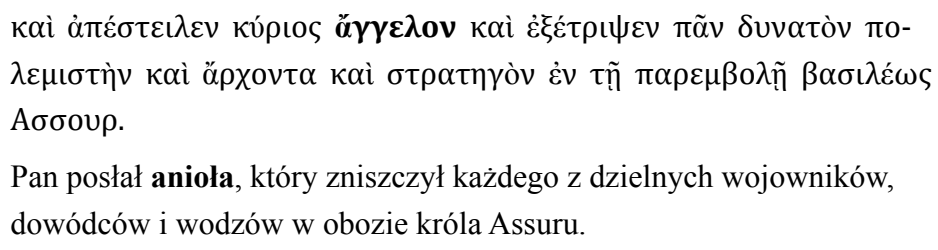 \\
\hline Iz 37,36 & $\mathrm{BH}$ & 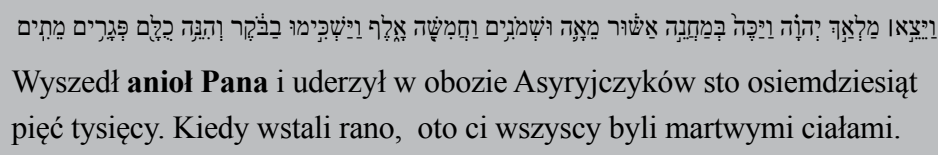 \\
\hline Iz 37,36 & LXX & 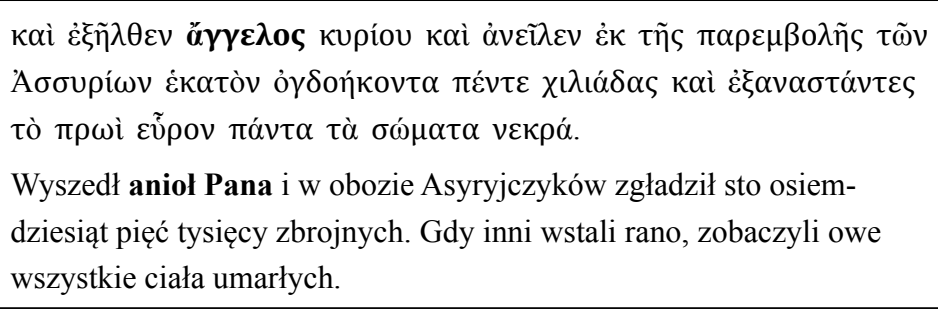 \\
\hline Syr 48,21 & $\mathrm{H}$ & 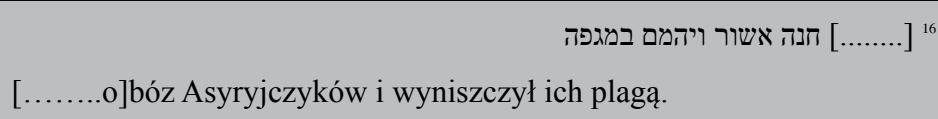 \\
\hline Syr 48,21 & LXX & 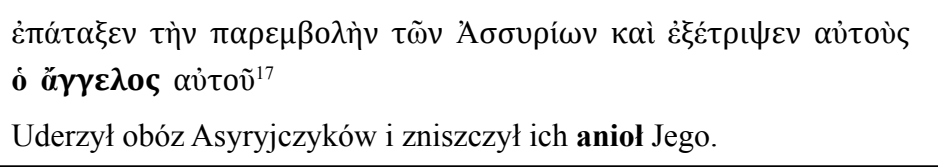 \\
\hline Syr 48,21 & Pes & 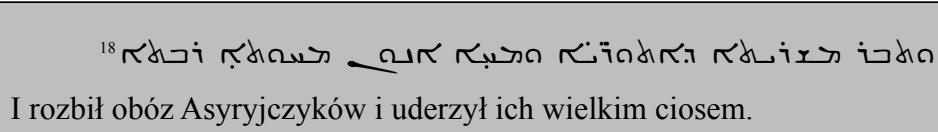 \\
\hline
\end{tabular}

16 P.C. Beentjes (red.), The Book of Ben Sira in Hebrew. A Text Edition of all Extant Hebrew Manuscripts and a Synopsis of all Parallel Hebrew Ben Sira Texts (Supplements to Vetus Testamentum 68; Leiden - New York - Köln: Brill 1997) 87. Na podstawie tekstu G i S rekonstrukcja uszkodzonego tekstu H mogłaby być następująca: חויך במה אשור ויהמם במגפה :I I uderzył obóz Asyryjczyków i wyniszczył ich plagą". A. Demitrów, Quattro oranti nell'Elogio dei Padri (Sir 44-49). Studio dei testi e delle tradizioni (Opolska Biblioteka Teologiczna 124; Opole: Wydawnictwo Wydziału Teologicznego Uniwersytetu Opolskiego 2011) 386, 441.

17 J. Ziegler (red.), Sapientia Iesu Filii Sirach (Septuaginta. Vetus Testamentum Graecum Auctoritate Academiae Scientiarum Gotteingensis editum XII/2; Göttingen: Vandenhoeck\&Ruprecht $\left.{ }^{2} 1980\right) 353$.

18 N. Calduch-Benages - J. Ferrer - J. Liesen (red.), La Sabiduria del escriba. Wisdom of the Scribe (Biblioteca Midrásica 26; Estella: Editorial Verbo Divino 2003) 258. 
Powyższe zestawienie ukazuje, iż wyrażenie ,anioł Pana/anioł” pojawia się w przekazie o ocaleniu Jerozolimy zarówno w $2 \mathrm{Krl}$ 19,35 (BH, LXX), jak i w tekstach zależnych od 2 Krl: Iz 37,36 (BH, LXX) i 2 Krn 32,21 (BH, LXX). 2 Krn 32,21 (BH, LXX) wskazuje na obecność „,anioła”, z uwypukleniem nakazu Pana (,posłał Pan”). Natomiast Księga Syracha w wersji hebrajskiej i syryjskiej pomija w swej relacji obecność anioła Pana. Z kontekstu poprzedzającego $(48,20)$ wynika, iż podmiotem działania jest sam Bóg, do którego lud zanosił błagania. Jednak wersja LXX umieszcza odniesienie do anioła (,anioł Jego"). Tylko 2 Krl 19,35 informuje, iż zajście miało miejsce w nocy. Dokładną liczbę zabitych Asyryjczyków (185 tysięcy) podaje zarówno $2 \mathrm{Krl}$ jak i Iz. 2 Krn ani nie podaje odniesień do czasu, ani do liczby zabitych, a jedynie wskazuje na ich rangę (,dzielni wojownicy, książęta i dowódcy” [BH]; „dzielni wojownicy, dowódcy i wodzowie” [LXX]). Natomiast Księga Syracha w wersjach hebrajskiej i syryjskiej podkreśla sam czyn (,plaga, cios”), bez odniesień do czasu, ilości osób czy ich rangi. Te drobne różnice budzą pytanie o zamysł autorów biblijnych w przedstawieniu tego ważnego wydarzenia. Nie ulega wątpliwości, iż wszyscy autorzy uwypuklają działanie Boga jako głównego podmiotu ocalającego mieszkańców Jerozolimy. Dlaczego jednak hebrajska i syryjska wersja Syr 48,21 pomija odniesienie do anioła, a grecka je przywołuje? Jakie znaczenie w tym przekazie miałaby zatem w tym kontekście obecność ,anioła Pana”?

\section{Kto zniszczył obóz Asyryjczyków według Syr 48,21?}

Przekaz o najeździe asyryjskim i cudownym ocaleniu Jerozolimy znajduje się w tekście Pochwaty Ojców (Syr 44-49), w części dotyczącej królów i proroków (Syr 46,1 - 49,10), w której Syrach prezentuje dzieje panowania króla Ezechiasza, mocno splecione z działalnością proroka Izajasza. Mędrzec opowiada tę historię w sposób syntetyczny, by pokazać jej najważniejsze elementy z punktu widzenia działania Boga podczas tych wydarzeń. Posiłkuje się obszernymi przekazami $2 \mathrm{Krl} \mathrm{18,1} \mathrm{-} \mathrm{20,21;} 2 \mathrm{Krn} 29$ - 32,33; Iz 36,1 - 39,8; 22,9-11, które dostosowuje do swojej koncepcji ${ }^{19}$. O ile koniec tekstu wypada w niekwestionowany sposób w 48,25 , to początek perykopy nastręcza pewne trudności ${ }^{20}$. Pojawiają się sugestie, że opisywana historia rozpoczyna się już,

19 Por. Demitrów, Quattro oranti, 367-368.

20 Zobacz na ten temat: L.H.M. Wieringen, ,Sirach 48:17-25 and the Isaiah-Book: Hezekiah and Isaiah in the Book of Sirach and the Reader-Oriented Perspective of the Isaiah-Book", Rewriting Biblical History: Essays on Chronicles and Ben Sira in honor of Pancratius C. Beentjes (red. J. Corley H. van Grol) (Berlin - New York: Walter de Gruyter 2011) 195. 
według tekstu H, w Syr 48,15e $\mathrm{e}^{21}$, kiedy mędrzec przechodzi od opisu Królestwa Izraela i jego upadku do dziejów Królestwa Judy i domu Dawida ${ }^{22}$. Sugeruje się też perykopa ma początek w Syr 48,16²3. Najczęściej uczeni wskazują jednak, że perykopa o panowaniu króla Ezechiasza zawiera się w Syr 48,17-2524. Czytając ten fragment w takich właśnie granicach, zauważa się ciekawą strukturę tego tekstu ${ }^{25}$ :

48,17: Wprowadzenie Ezechiasza

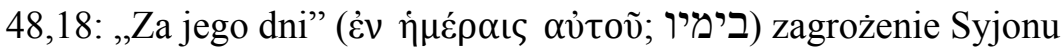

48,19-21: Ocalenie Syjonu (modlitwa i odpowiedź)

48,22: Wprowadzenie Izajasza

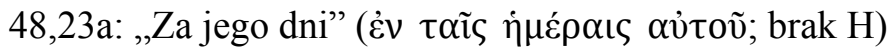

48,23b: Ocalenie króla

48,24-25: Inne zadania proroka

Przy królu Ezechiaszu pojawia się prorok Izajasz. W ten sposób mędrzec uwypuklił fakt, iż opowiadana historia kształtowana jest nie tyle przez odwagę króla,

21 Por. V. Hamp, Sirach (Die Heilige Schrift in deutscher Übersetzung, Echter - Bibel 13; Würzburg: Echter Verlag 1952) 135-136; P.W. Skehan - A.A. Di Lella, The Wisdom of Ben Sira (The Anchor Bible 39; New York - London - Toronto: Doubleday 1987) 536-538; J. Marböck, „Jesaja in Sirach 48,15-25: Zum Prophetenverständnis in der späten Weisheit", Schriftauslegung in der Schrift (red. O.H. Steck Odil) (Berlin: Walter de Gruyter 2000) 306-307; P.C. Beentjes, „Hezekiah and Isaiah: A Study on Ben Sira xlviii 15-25", New Avenues in the Study of the Old Testament (red. A.S. Van der Woude) (Leiden: Brill 1989) 80; P.C. Beentjes, „Is Search of Parallels: Ben Sira and the Book of Kings", Intertextual Studies in Ben Sira and Tobit (red. J. Corley) (Washington, D.C.: Catholic Biblical Association of America 2005) 123.

„In this section, Ben Sira turns his attention from the Northern Kingdom of Israel to the Southern Kingdom of Judah, and to one of its great kings, Hezekiah, and the outstanding prophet of his reign, Isaiah". Skehan - Di Lella, The Wisdom of Ben Sira, 537.

23 Por. G. Sauer, Jesus Sirach / Ben Sira (ATD Apokryphen 1; Göttingen: Vandenhoeck\&Ruprecht 2000) 328-330; A. Goshen-Gottstein, „Ben Sira's Praise of the Fathers: A Canon-Conscious Reading”, Ben Sira's God (red. R. Egger-Wenzel) (Berlin: Walter de Gruyter 2002) 259.

24 Por. W.O.E. Oesterley, The Wisdom of Jesus the Son of Sirach or Ecclesiasticus. Revised Version with Introduction and Notes (Cambridge: Cambridge University Press 1912) 329; G.H. Box W.O.E. Oesterley, "The Book of Sirach", The Apocrypha and Pseudepigrapha of the Old Testament with Introductions and Critical and Explanatory Notes to the Several Books (red. R.H. Charles) (Oxford: Clarendon 1913) 502; G. Snaith, Ecclesiasticus or The Wisdom of Jesus Son of Sirach (The Cambridge Bible Commentary on The New English Bible; Cambridge: Cambridge University Press 1974) 242-243; R.A.F. MacKenzie, „Ben Sira as Historian”, Trinification of the World: A Festschrift in Honor of F.E. Crowe (red. T.A. Dunne - J.M. Laport) (Toronto: Regis College Press 1978) 322; A. Minissale, Siracide (Ecclesiastico). Versione - Introduzione - Note (Roma: Edizioni Paoline 1980) 231-232; B.L. Mack, Wisdom and the Hebrew Epic. Ben Sira's Hymn in Praise of the Fathers (Chicago - London: The University of Chicago Press 1985) 211; B.M. Zapff, Jesus Sirach 25 51. Kommentar zum AT mit der Einheitsübersetzung (Die Neue Echter Bibel 39; Würzburg: Echter Verlag 2010) 363-366; Wieringen, ,Sirach 48:17-25”, 197; Demitrów, Quattro oranti, 371; J. Corley, Sirach (The Collegeville Bible Commentary 21; Collegeville, MN: Liturgical Press 2013) 138-139.

25 Por. Wieringen, „Sirach 48:17-25”, 198. 
ile poprzez słowo Boga. Opis postaci króla Ezechiasza rozpoczyna się od prezentacji jego prac budowlanych, fortyfikacji służących umocnieniu i obronie miasta przed wrogim najazdem oraz zabezpieczenia wody w mieście przez wykucie tunelu (Syr 48,17; por. 2 Krl 20,20; 2 Krn 32,5; Iz 22,9-11) ${ }^{26}$. Choć na pierwszy rzut oka nie ma tu żadnych odniesień do Boga ani tytułów króla, to opisana czynność umacniania miasta (rdzeń חזr) nawiązuje do imienia króla, które znaczy „YHWH czyni mocnym” (יחזקיהו), co od razu wskazuje na źródło siły i bezpieczeństwa narodu, a jednocześnie nawiązuje do innych zasłużonych budowniczych: Nehemiasza (Syr 49,13) i Szymona (Syr 50,1-4) ${ }^{27}$. Następnie mędrzec opisuje zwięźle najazd asyryjski króla Sennacheryba na Judę (Syr 48,18-21), co obszernie przekazują inne księgi (2 Krl 18,13-37; 2 Krn 32,9-19; Iz 36,1-22). W kontekście wersetów Syr 48,18-21 znajduje się przekaz o zniszczeniu obozu asyryjskiego. Mędrzec rozpoczyna tę relację od wystąpienia wysłanego przez Sennacheryba Rabsaka (Syr 48,18ab; 2 Krl 18,17.19.26-28), czyli „,wielkiego podczaszego", wysokiego urzędnika asyryjskiego, którego tytuł LXX uczyniła imieniem własnym ${ }^{28}$. Syrach nie relacjonuje długiej mowy Rabsaka, która miała na celu doprowadzić do poddania miasta, pokazuje natomiast znaczenie tego wydarzenia. Rabsak, który ,podniósł swą rękę przeciw Syjonowi”(Syr 48,18c) ${ }^{29}$, wystąpił przeciw Bogu YHWH i Jego potędze. Zostało to zinterpretowane jako bluźnierstwo i pycha, a jednocześnie znak wrogości i agresji (Syr 48,18d) ${ }^{30}$. Mędrzec mówi o emocjonalnej reakcji ludu: lęku i bólu (,,zadrżały serca i ręce ludu"), który wyraził poprzez obraz bólu rodzących $(\text { Syr } 48,19)^{31}$. Zaskakują-

26 Por. Wieringen, „Sirach 48:17-25”, 202; Demitrów, Quattro oranti, 400-405; D. Slager, A Handbook on Sirach (New York: United Bible Societies 2008) 969.

27 Skehan - Di Lella, The Wisdom of Ben Sira, 537; Demitrów, Quattro oranti, 399. Corley (Sirach, 138) stwierdza: ,In praising the good king Hezekiah, Ben Sira first mentions his building work in Jerusalem (as with Nehemiah in 49:13), because such work foreshadowed the achievements of the high priest Simeon (50:1-4) in the sage's own lifetime. Sirach 48:17 makes a Hebrew wordplay on Hezekiah's name: he «fortified» (hizzak) his city and also brought water into its midst (2 Kgs 20:20)". Por. Beentjes, „Hezekiah and Isaiah”, 81.

28 Por. Beentjes, „Hezekiah and Isaiah”, 82; Wieringen, „Sirach 48:17-25”, 202; Demitrów, Quattro oranti, 414-415.

29 W przekazach o mowie Rabska w 2 Krl, 2 Krn i Iz nie ma takiego gestu. Skehan - Di Lella (The Wisdom of Ben Sira, 538) widzą tu odniesienie do Iz 10,32 (,The expression «to shake his fist at Zion» [48:18c] is found also in Isa 10:32”), czemu sprzeciwiają się: Beentjes, „Hezekiah and Isaiah", 82; Demitrów, Quattro oranti, 414-415.

30 Por. Wieringen, „Sirach 48:17-25”, 202-203.

31 „Odniesienie do bólu kobiet rodzących może przywoływać tu obraz ciężkiej dotkliwej sytuacji, która sama przez się uniemożliwia urodzenie dziecka. W taki właśnie sposób opisał sytuację zagrożenia król Ezechiasz: «Ten dzień jest dniem utrapienia i kary, i hańby! Albowiem dojrzały dzieci do swoich narodzin, a nie ma siły do ich porodzenia!» (2 Krl 19,3; por. Iz 37,3). Z drugiej strony, ból rodzących stanowi metaforę dotkliwego, nagłego bólu, od którego nie ma ucieczki, co stanowi tu obraz kryzysu jednostki czy społeczności. W podobny sposób Iz 13,8 opisuje dzień sądu: «Ogarniają ich męki i boleści, wiją się z bólu jak ta, która rodzi; jeden na drugiego patrzy z osłupieniem, oblicza ich są w płomieniach». (Por. Iz 21,3; 26,17-18; Jr 6,24; 13,21; 22,23; 48,41; 
ce jest, że Syrach przywołuje dalej, oprócz emocji, konkretną odpowiedź ludu, choć według opisu $2 \mathrm{Krl}$ byli oni wezwani do milczenia wobec pogróżek ( $2 \mathrm{Krl}$ 18,36). Syr 48,20 wskazuje ich modlitwę: wołanie i wyciąganie rąk do Pana, co stanowi przeciwwagę postawy Rabska, jego gestu wyciągniętej ręki i słów. Według przekazu $2 \mathrm{Krl}$ 19,1-4; Iz 37,1-4 modlitwa dotyczyła przede wszystkim króla Ezechiasza, a według oszczędnego opisu 2 Krn 32,20 - króla Ezechiasza i proroka Izajasza ${ }^{32}$. Syrach natomiast mówi o modlitwie ludu. Być może sam fakt prośby ze strony posłańców Ezechiasza, którzy udali się do Izajasza w imieniu króla (por. $2 \mathrm{Krl} \mathrm{19,1-4),} \mathrm{mógł} \mathrm{być} \mathrm{widziany} \mathrm{jako} \mathrm{modlitwa,} \mathrm{błaganie} \mathrm{do}$ Boga o ratunek (por. $2 \mathrm{Krl} \mathrm{19,4;} \mathrm{Iz} \mathrm{37,4),} \mathrm{tym} \mathrm{bardziej} \mathrm{że} \mathrm{prorok} \mathrm{odpowiada}$ wysłańcom króla natychmiast, zanim on sam ją przedstawił Bogu. Wyrocznia prorocka Izajasza natychmiast zapewnia o Bożym ocaleniu ${ }^{33}$. W przekazie 2 Krl 19 oraz Iz 37 można zauważyć dwie fazy ocalającego orędzia Izajasza ${ }^{34}$. Pierwsza odpowiedź dana Ezechiaszowi odnosi się do wydarzeń, które zmienią plany króla asyryjskiego (2 Krl 19,5-8; Iz 37,6-8). Będzie to dotyczyć konfliktu z królem Kusz, Tirhaką ( $\mathrm{Krl}$ 19,9; Iz 37,9), co faktycznie miało miejsce i stało się przyczyną następnego poselstwa Sennacheryba do Ezechiasza. Pojawiły się więc kolejne pogróżki wobec Jerozolimy (por. $2 \mathrm{Krl} \mathrm{19,10-13;} \mathrm{Iz} \mathrm{37,10-13),} \mathrm{za-}$ warte w liście, który król musiał odczytać (2 Krl 19,14; Iz 37,14). W związku z tym Ezechiasz znów zanosił modlitwę do Pana (2 Krl 19,15-19; Iz 37,15-20), po której pojawiła się kolejna odpowiedź Izajasza, poprzedzająca cudowną, Bożą interwencję (2 Krl 19,20-34; Iz 37,21-35). A zatem całe opowiadanie pokazuje, że w narastającym konflikcie miedzy Sennaherybem i Ezechiaszem pojawia się dwukrotnie odpowiedź YHWH przez pośrednictwo proroka Izajasza. Syrach pomija kolejne etapy całego wydarzenia, ale wskazuje na natychmiastową odpowiedź ze strony Boga. Relacja prośba - odpowiedź pojawia się w syntetycznym przekazie Syr 48,20-21:

49,22; Mi 4,9; Ps 48,7). A zatem wydaje się, iż Syn Syracha wykorzystał istniejące już w innych tekstach obrazy oddające dosadnie grozę dramatycznej sytuacji swojego ludu, aby w bardziej realistyczny sposób oddać opisywaną rzeczywistość. Nie ma tu zatem odniesienia do konkretnej postaci kobiecej, a jedynie zauważa się próbę zobrazowania ekstremalnego bólu i cierpienia porównując go do bólu rodzącej kobiety” (J. Pudełko, „The (Apparent) Absence of Women in the Praise of the Ancestors (Sir 44-49)", The Biblical Annals 6/1 (2016) 117-118). Wieringen, ,Sirach 48:17-25", 204-205.

32 „Curiously, Ben Sira says the people «called upon the Most High God» (48:20a) and prayed with hands outstretched (48:20b), the usual manner of praying; but according to $2 \mathrm{Kgs} \mathrm{19:14-19} \mathrm{and} \mathrm{Isa}$ 37:15-20, it was Hezekiah alone who prayed" (Skehan - Di Lella, The Wisdom of Ben Sira, 538). Kronikarz nie przekazuje jednak treści modlitwy, jak to czyni 2 Krl 19 / Iz 37.

33 Por. Demitrów, Quattro oranti, 427-428.

34 Por. Demitrów, Quattro oranti, 428. 


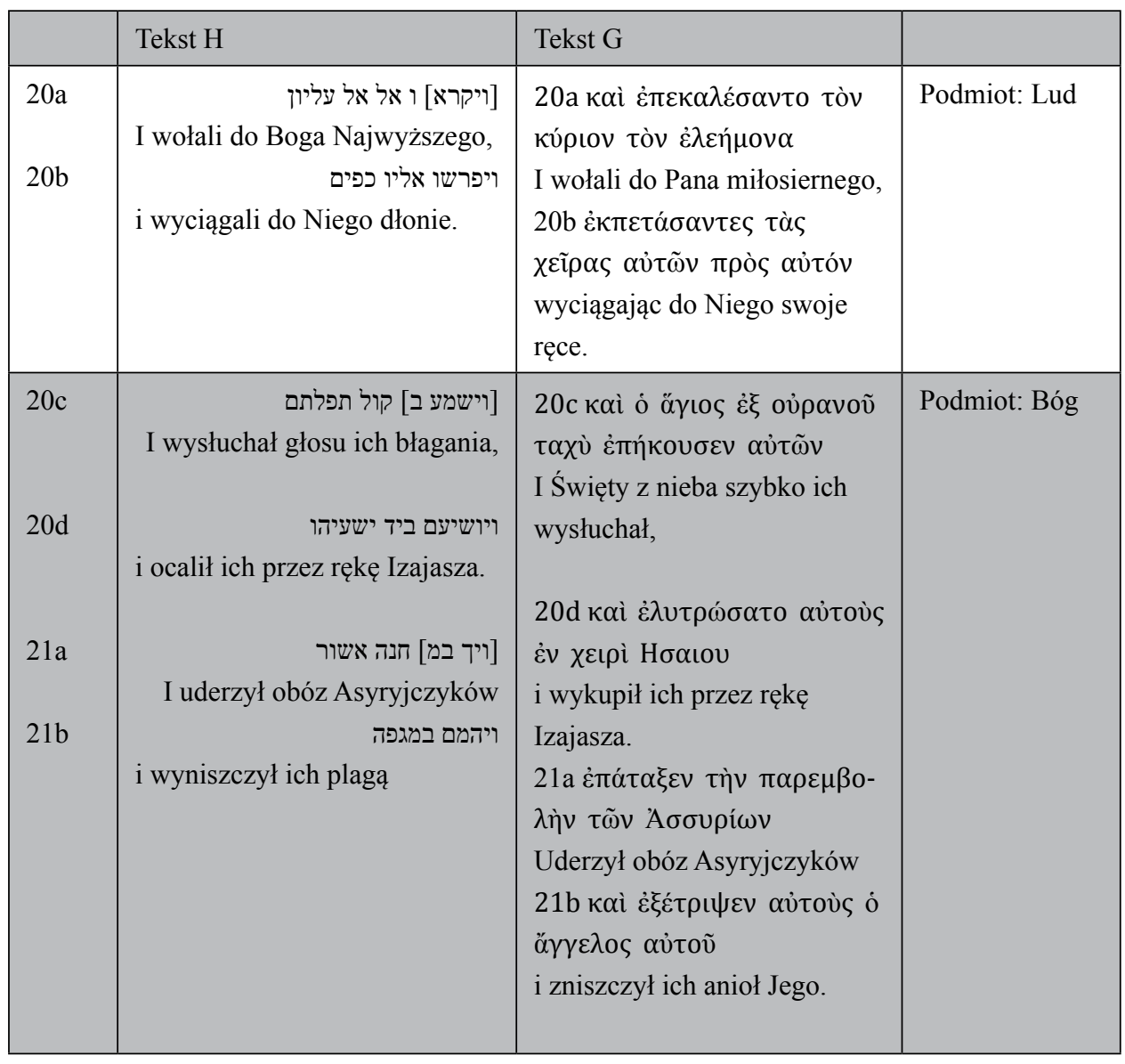

W Syr 48,20ab pojawia się czynność modlitwy, która zostaje wyrażona przez gest wyciągniętych rąk (w H dosłownie: dłoni) i błagania, które pochodzi od grupy ludzi (w liczbie mnogiej). Może ona dotyczyć zarówno ludu, który jest podmiotem we wcześniejszym wersecie Syr 48,19, jak i wymienianych w narracji $2 \mathrm{Krl} 19$ / Iz 37 Ezechiasza i Izajasza. Intensywna modlitwa jest tu wyrazem świadomości własnej bezsilności i zaufania wobec Boga. W konsekwencji pojawia się odpowiedź ze strony Boga i jest wyrazem Jego wierności przymierzu ze swoim ludem. Podniesiona ręka urzędnika asyryjskiego przeciw Syjonowi (Syr 48,18) odpowiada ręce proroka Izajasza, który interweniuje w obronie Syjonu (Syr 48,20d). Drżącym ze strachu rękom mieszkańców Jerozolimy $($ Syr 48,19) odpowiadają te same ręce, które następnie wznoszą się do modlitwy (Syr 48,20b). Być może przejście od lęku do ufnej modlitwy w postawie mieszkańców Jerozolimy thumaczy użycie w obu przypadkach liczby mnogiej jako podmiotu ${ }^{35}$. W Syr 48,20c H podmiot do-

35 Por. Wieringen, ,Sirach 48:17-25”, 204. 
myślnie odnosi się do Boga, do którego w 20ab była zanoszona modlitwa. W Syr

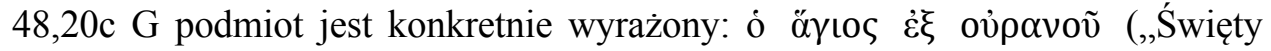
z nieba"). Odpowiedź Boga, zarówno w $\mathrm{H}$, jak i w $\mathrm{G}$ wiąże się z pośrednictwem

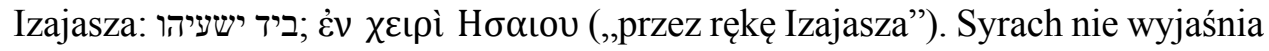
szczegółowo na czym polegało to pośrednictwo, ale kontekst całej sytuacji sugeruje modlitwę proroka $\mathrm{w}$ intencji ocalenia miasta oraz wyrocznię prorocką, która ogłosi klęskę króla asyryjskiego na korzyść mieszkańców Jerozolimy ${ }^{36}$. Beentjes zauważa, że podobnie jak w przypadku Syr 49,7 (ביד ישעיהו), ביד ירמיהו można by przetłumaczyć ,z powodu Izajasza”. Postawa Izajasza stała się więc ,inspiracją” dla króla Ezechiasza, który dzięki wskazaniom Izajasza czynił to, co się podobało Panu (Syr 48,22), a przez to otworzył się na moc Bożej interwencji wobec narodu ${ }^{37}$. Interwencja Boga została opisana w Syr 48,21ab. Wersja H mówi następnie o Bogu jako podmiocie domyślnym zdania: ויך במ] חנה אשור ויהמם במגפה ] (,I uderzył obóz Asyryjczyków, i wyniszczył ich plagą”). Natomiast wersja G

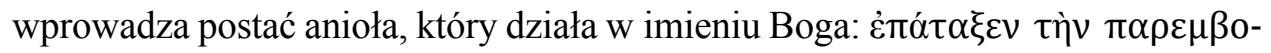

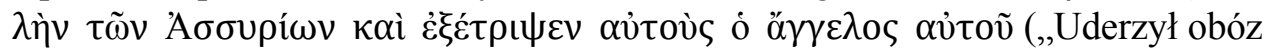
Asyryjczyków i zniszczył ich anioł Jego"). Może więc zastanawiać rozbieżność tych wersji, tym bardziej że przekazy hebrajskie o tym wydarzeniu wprowadzają postać anioła (2 Krl 19,35; Iz 37,21; 2 Krn 32,21). Zadziwia więc brak tego elementu w wersji hebrajskiej i syryjskiej Syr 48,21. Anioł Pana w przekazie $2 \mathrm{Krl}$ 19,35 stanowi figurę zdeterminowanego ,posłańca”, ,przedstawiciela” JHWH, który staje do konfrontacji z posłańcem króla asyryjskiego, szydzącego z Boga Izraela $(2 \mathrm{Krl} 18,35)^{38}$. Anioł Pana $\mathrm{w}$ tej ofensywie jest porównywany $\mathrm{z}$ aniołem śmierci, wykonawcą dziesiątej plagi egipskiej (Wj 12) ${ }^{39}$. W całym kontekście opowiadania o cudownym wyzwoleniu Jerozolimy z asyryjskiego oblężenia dominuje, podobnie jak w Księdze Wyjścia, konfrontacja dwóch potęg: asyryjskiej, wrogiej YHWH oraz izraelskiej, która w Nim pokłada ufność. Sennacheryb, przedsta-

36 „God answered their prayer (48:20c) and «saved them through Isaiah» (48:20d), who delivered to Hezekiah God's word that Sennacherib would not succeed in capturing Jerusalem but instead would be punished (2 Kgs 19:20-34; Isa 37:21-35)" (Skehan - Di Lella, The Wisdom of Ben Sira, 538).

37 Beentjes, "Hezekiah and Isaiah", 84.

38 Por. M. Cogan - H. Tadmor, II Kings: A New Translation with Introduction and Commentary (The Anchor Yale Bible 11; New Haven - London: Yale University Press 1988) 239.

39 Por. T.R. Hobbs, 2 Kings (WBC 13; Dallas, TX: Word Incorporated 1998) 282. Bar (,The Destroying Angel”, 255) zauważa: „The particular term «destroying angel» (malakh ha-mashhit) occurs twice in the Bible, in II Samuel 24:16 and its parallel, I Chronicles 21:15. Other allusions to this «destroyer» (mashit), can be found in Exodus 12:23 and Isaiah 54:16. The story of Sennacherib's siege of Jerusalem may also allude to a destroying angel (11 Kgs. 19:35; Isa. 37:36; II Chron. 32:21), although the term used there is simply malakh. In foe cultures of the ancient Near East, gods were believed to be responsible for death and destruction. The Bible, however, does not portray such a configuration. Instead, foe destructive agents act according to God's instruction: they are His messengers and it is the Lord who initiates death and destruction. We will see that the Bible refers to the angelic forces of destruction in a way that negates the ideas of neighbouring cultures". 
wiciel Asyrii i jej bóstw, posyła swojego posłańca Rabsaka, ogłaszącego rychłą zagładę Jerozolimy, której nikt i nic nie będzie w stanie pomóc. W odpowiedzi objawia się moc YHWH, który również działa poprzez swojego posłańca. Według 2 Krl 19,35; 2 Krn 32,21; Iz 37,21 jest nim ,anioł Pana”, tajemnicza postać dokonująca spustoszenia w obozie asyryjskim. Syr 48,21 H i S nie wymieniając anioła, uwypuklając działanie samego YHWH, który dotyka plagą Asyryjczyków ${ }^{40}$. Wydaje się, że w ten sposób zostaje zachwiana symetria pomiędzy Asyrią i Izraelem, gdzie każdy posiadał „wykonawcę” woli swego Boga i króla. Być może jednak Syrach chce tutaj zwrócić uwagę czytelnika na coś innego. Moc Boga objawia się w Jego słowie, wypowiadanym przez Jego posłańca (,,anioł”), którym jest sam Izajasz ${ }^{41}$. To słowo Pana, stwórcze i pełne mocy, kreuje nową rzeczywistość mieszkańców Jerozolimy: ocalenie. Moc głoszonego słowa odzwierciedla tematykę tej części Pochwały Ojców, w której znajduje się perykopa o Ezechiaszu i Izajasza (Syr 48,18-25). Syr 46,1 - 49,10 jest identyfikowana z kolejną częścią Biblii Hebrajskiej, a mianowicie zbiorem Proroków ${ }^{42}$. B.L. Mack wydziela w tym okresie etap zdobywania ziemi (Syr 46,1-12) oraz etap proroków i królów, będący w centrum historii $(\operatorname{Syr} 46,13-49,10)^{43}$. Podobnie określa ten etap dziejów J.L. Ska (Syr 46,1 - 49,10) $)^{44}$. Choć prorocy nie są jedynymi bohaterami, pojawia się terminologia prorocka, której brak w innych miejscach Pochwaly. Proroctwo jest tu też w szerszym rozumieniu ,obietnicą uczynioną przez Boga, zrealizowaną w życiu niektórych osób, które pełniąc swoją misję przewodnika innych i przekazując im wolę Boga, dały wkład w zmianę drastycznej sytuacji, prowadząc lud do zbawienia"45. I właśnie taka jest rola Izajasza w Syr 48,20-21. Zastanawia jednak obecność anioła Pana w Syr 48,21G. Tłumacz księgi mógł niewątpliwie sugerować się wcześniejszymi przekazami o tym wydarzeniu. Nie można jednak zapominać, że greckie tłumaczenie powstało po ważnym wydarzeniu w historii

40 "The angel of the Lord struck down one hundred and eighty-five thousand men in the Assyrian camp" (2 Kgs 19:35; cf. Isa 37:36); Ben Sira says that «God struck the camp» himself (48:21a). It is interesting that Ben Sira speaks of "a plague" routing the Assyrians (48:21b), whereas 2 Kgs 19:35 and Isa 37:36 say nothing of the kind". Skehan - Di Lella, The Wisdom of Ben Sira, 538. Corley (Sirach, 139) stwierdza: „Whereas 2 Kings 19:35 attributes sudden death in the Assyrian camp to the angel of the Lord, 48:21 ascribes it to a plague or epidemic".

41 Hamp (Sirach, 134) zaważa, iż w tym tekście ważne jest znaczenie imienia Izajasza: „JHWH jest zbawieniem“. Por. Snaith, Ecclesiasticus, 243; Beentjes, „Hezekiah and Isaiah”, 84.

42 Zob. na ten temat: L.G. Perdue, „Ben Sira and the Prophets”, Intertextual Studies in Ben Sira and Tobit (red. J. Corley) (Washington, D.C.: Catholic Biblical Association of America 2005) 132-154; P.C. Beentjes, „Prophets and Prophecy in the Book of Ben Sira”, Prophets, Prophecy, and Prophetic Texts in Second Temple Judaism (red. M.H. Floyd) (London: T \& T Clark 2006) 135-150.

43 Każdy z tych dwóch etapów zamyka wzmianka o bohaterach zbiorowych. W pierwszym są to Sędziowie (Syr 46,11-12), a w drugim Dwunastu proroków (Syr 49,10). Mack, Wisdom, 39-40.

44 J.L. Ska, „The Praise of The Fathers in Sirach (Sir 44-50) and The Canon”, The Exegesis of the Pentateuch: Exegetical Studies and Basic Questions (Forschungen zum Alten Testament 66; Tübingen: Mohr Siebeck 2009) 191.

45 Demitrów, Quattro oranti, 51. 
żydowskiej, jakim były powstania machabejskie. W przekazie, jaki niosą 1-2 Mch znajdują się odniesienia do cudownego ocalenia Jerozolimy z najazdu asyryjskiego za sprawą anioła Pana (por. 1 Mch 7,41-42; 2 Mch 8,19; 15,22), co motywowało modlitwę powstańców w ich aktualnych walkach. Obecność tajemniczych niebiańskich postaci pojawia się również w 2 Mch 3,24-30. Jest to legendarny opis obrony świątyni przed Heliodorem, który zamierzał złupić jej skarbiec. Został on jednak zaatakowany przez tajemniczego jeźdźca i wychłostany przez dwóch młodzieńców, których można identyfikować z aniołami, gdyż 2 Mch 3,24 wspomina o objawieniu się mocy „Władcy duchów”. Być może thumacz G wersji Księgi Syracha sugerował się różnymi przekazami i legendami związanymi z anielską interwencją w czasach machabejskich i umieścił ten element w Syr 48,21. W ten sposób przekaz historii został zaktualizowany do czasów odbiorców księgi ${ }^{46}$.

\section{Podsumowanie}

Przekazy biblijne thumaczą ocalenie Jerozolimy przed najazdem Sennacheryba interwencją Boga, który działa poprzez swojego ,posłańca” - anioła. W najpóźniejszym opisie tego wydarzenia w Syr 48,21, w wersji H i S, mędrzec z Jerozolimy daje własną, nieco odmienną od pozostałych interpretację wydarzenia. Pomija odniesienie do anioła i tłumaczy odwrót wojsk asyryjskich plagą zesłaną przez Boga. Przekaz Syracha uwypukla znaczenie proroka Izajasza w tej historii, przedstawiając również jego siłę oddziaływania na króla Ezechiasza. Modlitwa i błaganie ludu znajduje odpowiedź w orędziu proroka. To on przekazuje słowo Boga, które się wypełnia. Można więc przyjąć, że ,aniołem”, przez którego działa Bóg, jest tu prorok Izajasz, reprezentujący YHWH wobec potęgi wrogich sił Asyrii.

\section{Bibliografia}

Bar, S., „The Destroying Angel”, Jewish Bible Quarterly 42/4 (2014) 255-261.

Beentjes, P.C., „Hezekiah and Isaiah: A Study on Ben Sira xlviii 15-25”, New Avenues in the Study of the Old Testament (red. A.S. Van der Woude) (Leiden: Brill 1989) 77-88.

Beentjes, P.C. (red.), The Book of Ben Sira in Hebrew. A Text Edition of all Extant Hebrew Manuscripts and a Synopsis of all Parallel Hebrew Ben Sira Texts (Supplements to Vetus Testamentum 68; Leiden - New York - Köln: Brill 1997).

Beentjes, P.C., „Is Search of Parallels: Ben Sira and the Book of Kings”, Intertextual Studies in Ben Sira and Tobit (red. J. Corley) (Washington, D.C.: Catholic Biblical Association of America 2005) 118-131.

46 Por. Demitrów, Quattro oranti, 440-441. 
Beentjes, P.C., „Prophets and Prophecy in the Book of Ben Sira”, Prophets, Prophecy, and Prophetic Texts in Second Temple Judaism (red. M.H. Floyd) (London: T \& T Clark 2006) 135-150.

Box, G.H. - Oesterley, W.O.E., „The Book of Sirach”, The Apocrypha and Pseudepigrapha of the Old Testament with Introductions and Critical and Explanatory Notes to the Several Books (red. R.H. Charles) (Oxford: Clarendon 1913) 268-517.

Bright, J., Historia Izraela (przeł. J. Radożycki) (Warszawa: PAX 1994).

Calduch-Benages, N. - Ferrer, J. - Liesen, J. (red.), La Sabiduría del escriba. Wisdom of the Scribe (Biblioteca Midrásica 26; Estella: Editorial Verbo Divino 2003).

Chavalas, M., „Sennacherib's Invasion of Judah”, Fides et historia 27/2 (1995) 5-22.

Cogan, M. - Tadmor, H., II Kings: A New Translation with Introduction and Commentary (The Anchor Yale Bible 11; New Haven - London: Yale University Press 1988).

Corley, J., Sirach (The Collegeville Bible Commentary 21; Collegeville, MN: Liturgical Press 2013).

Demitrów, A., Quattro oranti nell'Elogio dei Padri (Sir 44-49). Studio dei testi e delle tradizioni (Opolska Biblioteka Teologiczna 124; Opole: Wydawnictwo Wydziału Teologicznego Uniwersytetu Opolskiego 2011).

Geyer, J.B., „2 Kings XVIII 14-16 and the Annals of Sennacherib”, Vetus Testamentum 21 (1971) 604-606.

Goshen-Gottstein, A., „Ben Sira's Praise of the Fathers: A Canon-Conscious Reading”, Ben Sira's God (red. R. Egger-Wenzel) (Berlin: Walter de Gruyter 2002) 235-267.

Grant, M., Dzieje dawnego Izraela (tłum. J. Schwakopf) (Warszawa: Państwowy Instytut Wydawniczy 1991).

Hamp, V., Sirach (Die Heilige Schrift in deutscher Übersetzung, Echter - Bibel 13; Würzburg: Echter Verlag 1952).

Herodot, Dzieje (tłum. S. Hammer) (Warszawa: Czytelnik 2015).

Hobbs, T.R., 2 Kings (WBC 13; Dallas, TX: Word Incorporated 1998).

Liverani, M., Nie tylko Biblia. Historia starożytnego Izraela (tłum. J. Puchalski) (Biblioteka humanisty; Warszawa: Wydawnictwo Uniwersytetu Warszawskiego 2010).

Luckenbill, D.D., The Annals of Sennacherib (Chicago: University Press 1924).

Mack, B.L., Wisdom and the Hebrew Epic. Ben Sira's Hymn in Praise of the Fathers (Chicago - London: The University of Chicago Press 1985).

MacKenzie, R.A.F., „Ben Sira as Historian”, Trinification of the World: A Festschrift in Honor of F.E. Crowe (red. T.A. Dunne - J.M. Laport) (Toronto: Regis College Press 1978) 312-327.

Mack, B.L., Wisdom and the Hebrew Epic. Ben Sira's Hymn in Praise of the Fathers (Chicago - London: The University of Chicago Press 1985).

Marböck, J., „Jesaja in Sirach 48,15-25: Zum Prophetenverständnis in der späten Weisheit”, Schriftauslegung in der Schrift (red. O.H. Steck Odil) (Berlin: Walter de Gruyter 2000) 305-319.

Minissale, A., Siracide (Ecclesiastico). Versione - Introduzione - Note (Roma: Edizioni Paoline 1980).

Nadav, N., „Updating the Messages: Hezekiah's Second Prophetic Story (2 Kings 19,9b-35) and the Community of Babylonian Deportees", Like a Bird in a Cage (red. L.L. Grabbe) (Sheffield: Sheffield Academic Press 2003) 201-220.

Oesterley, W.O.E., The Wisdom of Jesus the Son of Sirach or Ecclesiasticus. Revised Version with Introduction and Notes (Cambridge: Cambridge University Press 1912). 
Perdue, L.G., „Ben Sira and the Prophets”, Intertextual Studies in Ben Sira and Tobit (red. J. Corley) (Washington, D.C.: Catholic Biblical Association of America 2005) 132-154.

Piwowar, A., Historia Izraela czasów Starego Testamentu. Od patriarchów do podboju przez Rzymian (Materiały Pomocnicze do Wykładów z Biblistyki 12; Lublin: Wydawnictwo KUL 2013).

Pudełko, J., „The (Apparent) Absence of Women in the Praise of the Ancestors (Sir 44-49)”, The Biblical Annals 6 (2016) 107-126.

Rosenbaum, J., „Hezekiah, King of Judah”, The Anchor Yale Bible Dictionary (red. D.N. Freedman) (New York: Doubleday 1990) III, 189-193.

Sauer, G., Jesus Sirach / Ben Sira (ATD Apokryphen 1; Göttingen: Vandenhoeck\&Ruprecht 2000).

Ska, J.L., „The Praise of The Fathers in Sirach (Sir 44-50) and The Canon”, The Exegesis of the Pentateuch: Exegetical Studies and Basic Questions (Forschungen zum Alten Testament 66; Tübingen: Mohr Siebeck 2009) 184-195.

Skehan, P.W. - Di Lella, A.A., The Wisdom of Ben Sira (The Anchor Bible 39; New York - London - Toronto: Doubleday 1987).

Slager, D., A Handbook on Sirach (New York: United Bible Societies 2008).

Smend, R., Die Weisheit des Jesus Sirach erklärt (Berlin: Verlag von Georg Reimer 1906).

Snaith, G., Ecclesiasticus or The Wisdom of Jesus Son of Sirach (The Cambridge Bible Commentary on The New English Bible; Cambridge: Cambridge University Press 1974).

Stachowiak, L., „Imperium Neoasyryjskie a Juda w II. połowie w. VIII”, RTK 29/1 (1982) 29-44.

Warzecha, J., Historia dawnego Izraela (Warszawa: Wydawnictwo Uniwersytetu Kardynała Stefana Wyszyńskiego 2005).

Wieringen, L.H.M., „Sirach 48:17-25 and the Isaiah-Book: Hezekiah and Isaiah in the Book of Sirach and the Reader-Oriented Perspective of the Isaiah-Book", Rewriting Biblical History. Essays on Chronicles and Ben Sira in Honor of Pancratius C. Beentjes (red. J. Corley - H. van Grol) (Berlin - New York: Walter de Gruyter 2011) 191-210.

Zapff, B.M., Jesus Sirach 25 - 51. Kommentar zum AT mit der Einheitsübersetzung (Die Neue Echter Bibel 39; Würzburg: Echter Verlag 2010).

Ziegler, J. (red.), Sapientia Iesu Filii Sirach (Septuaginta. Vetus Testamentum Graecum Auctoritate Academiae Scientiarum Gotteingensis editum XII/2; Göttingen: Vandenhoeck\&Ruprecht ${ }^{2} 1980$ ). 